\title{
ÁREAS PROTEGIDAS, POPULAÇÓES TRADICIONAIS DA AMAZÔNIA E NOVOS ARRANJOS CONSERVACIONISTAS
}

\section{Ana Tereza Reis da Silva}

http://orcid.org/0000-0001-8204-0732

Universidade de Brasília (UnB), Brasília - DF, Brasil. E-mail: anaterezareis@unb.br.

DOI: $10.1590 / 349905 / 2019$

\section{Introdução}

O reconhecimento de que é possível aliar conservação ambiental e modos de vida de Povos e Comunidades Tradicionais (PCTs) desencadeou a criação de dispositivos legais visando garantir a permanência dessas populações em seus territórios. ${ }^{1}$ Essa reviravolta tem sido construída pelo protagonismo político de indígenas, quilombolas e outros sujeitos da tradição. Um marco importante desse processo foi a Aliança dos Povos da Floresta, movimento que, na década de 1980, unificou seringueiros, castanheiros e indígenas da Amazônia na luta por terra e na defesa de seus territórios, de seus bens naturais e de suas diferentes formas de manejo e uso. Desde entâo, esse movimento toma vulto, se capilariza, gera políticas que associam proteção ambiental,

Artigo recebido em: 13/03/2017

Aprovado em: 05/02/2018 reconhecimento identitário e designação territorial, visibilizando a sociobiodiversidade brasileira.

Ribeirinhos, pescadores artesanais, caboclos da Amazônia, quebradeiras de coco, comunidades de fundo de pasto, faxinalenses, caiçaras, geraizeiros, pomeranos, povos de terreiro, retireiros, entre outras comunidades tradicionais, que antes eram vistas como entraves ao desenvolvimento e/ou à conservação, contam hoje com vários instrumentos legais para a defesa de seus direitos. Uma defesa que se dá tanto perante o Estado, que avança com seus projetos de desenvolvimento desconsiderando as pessoas, quanto em relação aos interesses do capital e suas estratégias de mercado (agronegócio, mineração, megaprojetos de infraestrutura etc.).

Contudo, se essas populaçôes finalmente podem reivindicar a compatibilidade de seus modos de vida com a conservação, ainda persiste no campo da proteção ambiental uma orientação binária que defende "desabitar a natureza dos humanos para 
que outras formas de vida possam habitar livremente" (Bensusan e Prates, 2014, p. 35). Com efeito, os novos arranjos conservacionistas, embora representem um avanço, não póem fim aos conflitos. As Unidades de Conservação de uso sustentável são espaços em disputa, onde se tencionam, por um lado, os interesses sociais pelo território, como meio de produção material e imaterial da vida, e, por outro, os interesses que pretendem destinar esses espaços exclusivamente à conservação e aos interesses de mercado que permeiam muitas das práticas de conservação incentivadas dentro das unidades.

Neste artigo, apresento os contornos que esses conflitos assumem na Floresta Nacional do Tapajós (Flona Tapajós), assim como analiso as consequências que a criação dessa unidade trouxe à população residente no território. Os dados e as falas que serão reproduzidos ao longo do texto foram levantados entre novembro de 2013 e início de 2017, por meio de visitas in loco, durante as quais entrevistei gestores, conversei com lideranças e realizei rodas de conversa com moradores. ${ }^{2}$

$\mathrm{Na}$ primeira seção do artigo - dividida em três subseçóes -, descrevo o processo de criação da Flona, apresento suas características organizativas e populacionais e analiso em que medida as restriçôes impostas à população podem estar ligadas às suas heranças socioculturais diversas. Mais precisamente, problematizo em que medida o modo próprio de existência dessa população motivou, por parte da gestáo da unidade, a suspeição de seu pertencimento à tradição e, consequentemente, a proibiçáo de certos usos e manejos, e a introdução de práticas consideradas mais sustentáveis. Nesse debate, contraponho a visão essencialista de identidade, que prescreve o pertencimento à tradição a partir de preconceitos e estereótipos, e a noção de Povos e Comunidades Tradicionais como um instrumento político-jurídico que auxilia os sujeitos da tradição na defesa de seus territórios. A partir dessas reflexóes, e reconhecendo a herança indígena e o vínculo histórico, cultural e social da população da Flona Tapajós com as chamadas Sociedades Caboclas Amazônicas, argumento em favor de seu pertencimento à tradiçáo e da compatibilidade entre seus modos de vida e a conservação.

$\mathrm{Na}$ segunda seção, também dividida em três subseções, analiso como o "direito de ficar" "impôs condicionalidades" à população, isto é, impôs restrições de uso e introduziu novas práticas que têm modificado as relaçóes comunitárias e as dinâmicas socioeconômicas do lugar. Foco em três situaçôes emblemáticas: (1) o abandono dos roçados de mandioca, que gerou o sumiço da farinha e o comprometimento de uma rede de relaçóes baseada na solidariedade e na reciprocidade; (2) a emergência do turismo e as transformaçóes que ele suscita nas formas de produção da existência, na vida cotidiana e no acesso aos espaços comuns, que agora são visados pelos turistas; (3) o manejo florestal em larga escala que, ao ser alçado a uma das mais importantes atividades geradoras de renda, instalou novas hierarquias nas relaçôes interpessoais/comunitárias/intercomunitárias e a mercantilização da floresta. Analiso esse processo de coisificaçáo da natureza a partir do que Almeida (2013) chama de guerra ontológica.

As reflexôes apontam que o "direito de ficar" impôs condicionalidades (restrições e novas práticas) que nem sempre foram democraticamente discutidas, mas que alteram o modo de vida que justificou a permanência das pessoas no território. Logo, os arranjos conservacionistas, ao mesmo tempo que criam possibilidades efetivas de justiça territorial (o direito de ficar), impóem dificuldades para a efetivação da justiça socioambiental, o que envolve reconhecer a legitimidade dos diferentes usos que essas populaçóes fazem dos bens naturais.

\section{"Nem índio é"}

Desde sua criação, pelo Decreto n. 73.684 de 19 de fevereiro de 1974, a Floresta Nacional do Tapajós é uma área de conflito socioambiental e fundiário envolvendo a população tradicional ribeirinha (cabocla), assentados rurais do Instituto $\mathrm{Na}$ cional de Colonização e Reforma Agrária (Incra) e o Estado brasileiro. Uma das mais antigas da Amazônia, a unidade está localizada no oeste do Pará, no corredor de unidades de conservação estabelecido em fins de 1990, entre o rio Tapajós a oeste, a BR-163 (Cuiabá-Santarém) a leste, o rio Gupaí e a BR-230 (Transamazônica) ao sul e o município de Belterra ao norte. Sua extensão de $527 \mathrm{mil}$ hectares abarca áreas dos municípios de Belterra e 
Aveiro (Ibama-MMA, 2004). A área designada no decreto de 1974 abrangia cerca de 28 comunidades dos municípios de Belterra e Aveiro. Em 2012, quatro comunidades localizadas na BR-163 (Santarém-Cuiabá) e cinco comunidades concernentes ao município de Aveiro foram desmembradas. Hoje a unidade conta com dezenove comunidades, sendo três delas autodeclaradas indígenas do povo Munduruku, ${ }^{3}$ e população aproximada de 5 mil pessoas.

A ameaça da perda do território levou as comunidades a se organizarem em associaçóes comunitárias e intercomunitárias. A partir de 2007 , quando o Instituto Chico Mendes de Conservação da Biodiversidade (ICMBio) assumiu a gestáo da unidade, a participação da população nas decisōes relacionadas à gestáo do território dá-se de forma representativa, pela atuação dos presidentes das associações intercomunitárias no Conselho Consultivo da Unidade. As associaçōes intercomunitárias mais atuantes são Aita e Asmiprut, ambas também se revezam na presidência da cooperativa, que desenvolve manejo florestal extensivo no território (tratarei dessa atividade nas seções subsequentes).

No ano de 2000, a garantia de permanência se mostrava mais efetiva por força da criação do Sistema Nacional de Unidades de Conservaçáo (SNUC), que tanto previa Unidades de Conservação (UC) com moradores em seu interior quanto confirmava a legalidade do Decreto n. 1.298/1994, que já autorizava a permanência de populaçōes tradicionais em Flonas. Contudo, para além desse amparo legal, outras questóes também incidiram na definiçấo de quem sairia ou ficaria na unidade: $:^{4}$ a proximidade de certas comunidades com áreas urbanas, o que era visto pelos agentes da conservação como um fator de alteração dos modos de vida tradicionais; as atividades de sustento das famílias, sobretudo aquelas que as autoridades consideravam incompatíveis com a conservação, como a criação de gado, roçado em área de mata e comercialização de excedentes; as incertezas dos moradores quanto aos rumos que a vida tomaria na unidade, o que fez com que muitas famílias optassem pela indenização como um caminho mais seguro; e, ainda, a pressão do Estado para que as famílias comprovassem que seu vínculo com o território era anterior ao decreto de criação da Flona.
Após três décadas de resistência e negociação, mesmo quando o direito de ficar era dado como certo, persistia, segundo relatos de moradores, um clima de angústia e dúvida quanto à exigência de documentos que atestassem relaçóes de parentescos e vínculos comunitários (certidōes de nascimento, casamento, batismo, declaraçôes das associaçôes comunitárias e sindicais e/ou de lideranças comunitárias). Apesar da histórica presença de igrejas e sindicatos no território, essas comunidades sempre mantiveram uma dinâmica social e cultural de forte tradição oral, na qual o papel não gozava de grande prestígio (Leroy, 1991). Além da humilhação e do desgaste de reunir uma série de documentos, havia o temor de que eles fossem rejeitados. Segundo uma importante liderança local: "o Estado que nunca teve aqui para um nada, quando veio, foi só para roubar o que nós tinha, ameaçar e fazer exigências" (Comunitário 4).

A exigência do papel revelava mais sobre a visáo do Estado acerca das comunidades rurais amazônicas do que sobre o pertencimento da população e seu direito histórico ao território. $\mathrm{O}$ mesmo se pode dizer em relaçáo a outras situaçóes de vida, corriqueiras nas comunidades ribeirinhas da Amazônia, que foram muitas vezes acionadas para colocar em xeque o pertencimento e a compatibilidade dos modos de vida da populaçáo com as práticas de conservação que se pretendia imprimir na unidade.

As comunidades que habitam a Flona Tapajós são reconhecidas e se autoidentificam como "caboclos, caboclos do Tapajós, caboclos da Flona" (Ioris, 2000, p. 6). Embora essa autonomeação seja recorrente, convém destacar que pesquisadores como Vaz (2004) afirmam haver entre os moradores do Tapajós uma aversão a essa denominaçáo e uma propensão maior de reconhecimento da descendência indígena. De fato, os processos de autoidentificação indígena, que várias comunidades ribeirinhas do Tapajós colocaram em movimento a partir da década de 1990, demonstram haver aí um processo aberto de ativação e reavivamento étnico. De todo modo, usarei a nomeaçáo "caboclo" para designar essas populações, entendendo, contudo, que elas também são, ou podem vir a ser, indígenas em processo de reinvenção e afirmação de suas identidades. 
Em razão da proximidade com as áreas urbanas do entorno, a população transita frequentemente entre o campo e a cidade por conta de suas relaçóes de parentesco, para a comercialização de seus excedentes e para o acionamento de bens e serviços; ausentam-se de suas comunidades por tempos curtos ou prolongados visitando parentes em outras regióes, em razão de problemas de saúde ou para garantir o estudo dos filhos, o que não implica, todavia, a quebra do vínculo com a comunidade; praticam, de modo associado, o roçado de mandioca (com aceiro), a caça, a pesca, o extrativismo de produtos florestais não madeireiros para o consumo e o comércio e a criação de gado ou de outros animais de pequeno porte; mantém unidades familiares separadas (embora sem cerca) e compartilham áreas comuns destinadas à caça, à pesca, ao roçado e ao extrativismo.

$\mathrm{Na}$ avaliação dos gestores da unidade, contudo, "o comércio de excedentes, a criação de gado, o fogo e o roçado em mata fechada são insustentáveis em uma Floresta Nacional”. Além disso, "o uso dessas práticas só prova que eles não são índios, nem tradicionais verdadeiros". Logo, um dos desafios da gestão é ensiná-los “a ser sustentáveis e reorientar seus modos de vida para que eles se tornem compatíveis com a conservação" (Entrevistado 1). ${ }^{5}$ Essas falas expressam o que Diegues (2004) definiu como o mito moderno da natureza intocada, ou o que Escobar (2010) designa como um dualismo que não participa dos modelos de natureza praticados pelas populaçóes locais. Ora, ainda que algumas dessas atividades não sejam permitidas em áreas protegidas, o fato de a floresta estar de pé não se apresenta aí como um teste do tempo que dá provas de que essas formas de manejo e regimes de uso comum são compatíveis com a conservação?

Ignora-se, ademais, que "as relações específicas imbuídas na noção do lugar não devem ser confundidas com as da noção de originalidade, isto é, o fato de ser o primeiro grupo a ocupar uma área geográfica” (Little, 2002, p. 263). Do mesmo modo, "ser de um lugar não requer uma relação necessária com etnicidade ou com raça", mas se expressa pelas afetividades e vínculos que são estabelecidos com determinado espaço físico (p. 264). Logo, o pertencimento da população da Flona poderia ser considerado levando-se em conta uma multiplicidade de elementos: suas heranças indígenas, sua emergência histórica como grupo a partir de processos de etnogêneses, suas relaçôes de parentesco com pessoas do lugar, suas relaçôes com o ambiente biofísico, seus regimes de uso comum e suas formas de manejo que se mostram sustentáveis.

O que aqui se observa, sob muitos aspectos, é a proeminência de um imaginário que supóe essa população como não portadora de marcadores étnicos "verdadeiramente" tradicionais (quilombolas e indígenas), sendo vista, portanto, como uma população "não autêntica", cujos modos de vida se mostram incompatíveis com os desígnios da conservação. As limitações e restrições adotadas podem estar relacionadas a uma compreensão depreciativa das populações ribeirinhas (caboclos amazônicos), que, por conta de suas heranças indígenas e não indígenas, associam formas diversas de uso do território e manejo dos bens naturais.

A suspeição que coloca à prova o pertencimento dos moradores ao território e a "vocação ecológica de seus modos de vida”, remete-nos à herança colonial que denegou e subalternizou historicamente a identidade cabocla, e que incide, ainda hoje, sobre as formas como essa "(des)identidade" tem sido assumida:

Caboclo é um termo depreciativo usado para indicar pessoas que não se sabiam com a mesma identidade e que pertenciam à escala mais baixa da sociedade colonial amazônica. Não obstante, presente no tecido intersubjetivo dessa sociedade, por meio de uma equação complexa, o termo acabou sendo usado por essa mesma população para se autorreferir em relação às expectativas do dominador. A carga simbólica negativa [...] passou a ser reconhecida como tal e a veicular um tipo de violência simbólica que se assemelha a autocensura, prenhe de um sentimento confuso que ora pertencia à vergonha, ora à culpa, ora ao saber-se inferior (Castro, 2013, pp. 434-435).

Como um pertencimento supostamente de "segunda categoria”, a identidade cabocla é, ao mesmo tempo, visibilizada e invisibilizada. Uma contraidentidade assumida e censurada que é, quase sem- 
pre, adjetivada ou referida como sinônimo de suas identidades relacionais: ribeirinhos, pescadores, extrativistas, novos índios, varzanteiros. Embora seja tão válida quanto suas identidades relacionais, tudo se passa como se a identidade cabocla intersubjetiva e inevitável que é - precisasse ser eufemizada para expurgar sua carga negativa, para ser aceita como identidade possível e crível.

Segundo Adams et al. (2006), persistem dois pressupostos depreciativos acerca da paisagem cultural e social dos povos da Amazônia. O primeiro diz respeito à representação da regiáo como um espaço precariamente ocupado pelo outro primitivo (povos indígenas), desde sempre subordinado aos desígnios da natureza. O segundo, consequência do primeiro, consiste na visão de que a natureza e os povos da natureza (frequentemente representados como incivilizados) constituem fatores determinantes do suposto atraso da regiâo e de seus sistemas sociais.

Sem um referente teórico que lhes fizesse justiça, as comunidades caboclas da Amazônia foram vistas, muitas vezes, como antagônicas das sociedades indígenas, isto é, os outros falsificados quando comparados com os outros primitivos originais. Embora, como sugere Nugent (2006), a própria antropologia reconheça que os caboclos herdam inegavelmente elementos sociais e culturais dos povos indígenas.

Por fim, a subalternização de suas identidades estaria relacionada, também, a seus modos de vida: diversos e não especializados, que combinam e reinventam processos socioeconômicos de povos indígenas, colonizadores e neocamponeses; assentamentos humanos que transitam entre áreas de várzea e de terra firme, as quais escondem uma complexa e vasta heterogeneidade; mecanismos econômicos e sociais de sobrevivência que acionam relaçóes e serviços do campo e da cidade, rompendo com as rígidas fronteiras entre o urbano e o rural (Adams et al., 2006).

Essas características também estão presentes entre os caboclos da Flona Tapajós e conformam suas especificidades de comunidade tradicional. Contudo, e não raro, essas mesmas características foram (e ainda são) usadas contra essa população; seja para enquadrá-la ou na intenção de forjar um discurso de autoridade que demonstre que suas práticas precisam ser "ajustadas" para se tornarem compatíveis com os "propósitos da conservação".

Povos e comunidades tradicionais: um conceito em construção

Ao contrário dos indígenas, quilombolas e seringueiros, até recentemente, os caboclos amazônicos, assim como outras sociedades tradicionais, não dispunham de nenhum dispositivo legal que lhes assegurasse $\mathrm{o}$ direito às terras onde habitam. Mudanças nesse cenário se devem à criação de importantes instrumentos jurídicos: o Sistema Nacional de Unidades de Conservação, o Decreto n. 6.040/2007, que institui a Política Nacional de Desenvolvimento Sustentável dos Povos e Comunidades Tradicionais, o Decreto n. 8.750/2016, que institui o Conselho Nacional de Povos e Comunidades Tradicionais, entre outros.

Decorrente também do papel estratégico desempenhado pela Comissão Nacional de Povos e Comunidades Tradicionais (CNPCT) - transformada em Conselho Nacional -, ${ }^{6}$ nos últimos dezesseis anos houve expressivo aumento de processos de autorreconhecimento e reivindicação territorial. Esses avanços têm-se traduzido na construção de novas formas de destinação e/ou regularização de territórios tradicionalmente ocupados, visibilizando e legitimando as mais diversas identidades, formas de uso e regimes territoriais. Há uma vasta literatura que analisa as mudanças decorrentes dos dispositivos legais criados para esse fim, bem como os avanços logrados e os desafios de implementação que ainda se colocam (Favilla, 2017; Porto, Pacheco e Leroy, 2013; Almeida, 2009; Little, 2002, 2006; Almeida, 2006; Shiraishi Neto, 2007).

Em sentido mais amplo, o que Moscovici (2007) chama de polimerização da ecologia - o movimento político-ecológico que colocou a natureza no centro do debate por uma cultura de vida em oposição a uma cultura de morte - colaborou para a emergência e consolidação de um contradiscurso político-epistêmico em defesa do papel que as sociedades tradicionais desempenham, historicamente, na proteção de seus ecossistemas. Pesquisas desenvolvidas no campo buscam analisar empiricamente as dinâmicas sociais ambientais e os manejos ancestrais praticados por esses grupos, com o obje- 
tivo de mapear sua participação na diversificação da biodiversidade e na manutenção das florestas em pé (Bensusan e Prates, 2014).

Ocorre, não obstante, que, se a "vocação ecológica" dos povos indígenas e quilombolas tem sido, desde os anos de 1980, amplamente reconhecida, o mesmo não se deu em relação aos modos de vida dos caboclos da Amazônia e de outras comunidades tradicionais (varzanteiros, extrativistas, retireiros, pescadores artesanais, caiçaras, quebradeiras de coco, geraizeiros, entre outros).

Em relação a essas populaçóes, muitas vezes identificadas como "sem marcadores étnicos", a visão começou a mudar com a emergência da noção de Povos e Comunidades Tradicionais. A abrangência quase lacunar desse conceito é, todavia, motivo de controvérsias. Para alguns autores, seu caráter amplo parece pulverizar as particularidades e características próprias de cada comunidade, concorrendo ainda mais para sua invisibilização. Para outros, é justamente essa elasticidade que permite abrigar os mais diversos modos de vida que foram se constituindo, sobrevivendo e resistindo ao longo desses mais de 500 anos de encontro colonial (Alier, 2011; Cunha, 2009; Almeida, 2009; Diegues, 2008).

A sociogênese do conceito e seus usos políticos e sociais se deram em diferentes frentes. No contexto de expansão das fronteiras do desenvolvimento hegemônico, ele foi acionado para designar grupos sociais e seus territórios ameaçados por investidas do Estado ou de setores a ele vinculados. No contexto ambientalista, surge como forma de identificação das populações usuárias ou residentes em unidades de conservação, cujo projeto de preservação as definia como obstáculo à proteção ambiental, ou, em outra direção, como estratégia para designar esses grupos como aqueles que historicamente desenvolveram formas de uso e manejo compatíveis com a proteção da natureza (Little, 2002).

A luta dos seringueiros do Acre, em meados dos anos 1980, visibilizou esse debate, contribuindo para que a associação entre conservação e modos de vida tradicionais fosse reconhecida como uma estratégia que poderia ser exitosa em outros contextos. Assim, o conceito de povos e comunidades tradicionais, que intencionava traduzir os modos de vida que não expressavam a "tradição" nos moldes usualmente pensados (indígenas e quilombolas), foi pouco a pouco sendo "habitado por gente de carne e osso" (Almeida, 2009, p. 278). Por grupos que têm em comum:

[...] uma história de baixo impacto ambiental e demonstram, no presente, interesse em manter ou recuperar o controle sobre o território que exploram. Além disso, e acima de tudo, estão dispostos a uma negociação: em troca do controle sobre o território, comprometem-se a prestar serviços ambientais (Idem, p. 279).

Ao longo da primeira década do século XXI, o conceito tem desempenhado um papel importante nos debates acadêmicos e na conformação de dispositivos jurídicos que visam garantir os direitos identitários e territoriais das mais diversas comunidades tradicionais, convertendo-se efetivamente em um instrumento estratégico na luta por justiça socioambiental. Essa nova conduta territorial dos povos e comunidades tradicionais, cujo efeito político mais notável foi forçar o Estado brasileiro a reconhecer a existência de distintos regimes de propriedade, tem fortalecido a luta pelo reconhecimento da legitimidade de determinadas formas de uso e, correlatamente, pela conformação de instrumentos jurídicos de designação territorial que sejam mais compatíveis com a realidade empírica e histórica da ruralidade brasileira (Little, 2002).

Para Almeida, os sujeitos que reivindicam marcadores identitários (indígenas, quilombolas, caboclos, caiçaras, entre outros) "são entes interacionais cuja existência está ligada a uma história de reconhecimento [...], que começa com a existência para o outro". E, nesse caso, o outro é o Estado. Assim, reconhecendo-se que "a existência e a não existência de entes é campo de luta e de poder", a reivindicação do reconhecimento identitário é uma forma de fazer frente às perspectivas universais e reducionistas, que só reconhecem categorias identitárias genéricas e prefixadas - "indivíduos cidadãos" que têm o nefasto poder de apagar as diferenças (Almeida, 2013, pp. 22-24).

Sendo assim, para quilombolas, indígenas e todas as demais identidades tradicionais que têm sido 
visibilizadas e reivindicadas nos últimos trinta anos no país, "a luta pelo reconhecimento tem como foco o reconhecimento/produção da existência. Não é uma questão semântica ou de ressemantização, e sim de história de constituição real de entes sociais" (Idem, p. 23). Os povos e as comunidades tradicionais não se descobriram como tais agora, mas vêm se construindo historicamente, com a consolidação de seus costumes, saberes e modos próprios de viver, assim como na luta por reconhecimento enquanto existente (Idem). Esses sujeitos há muito compreenderam que se autonomear e nomear seus modos próprios de existência encurtam as distâncias para o acesso a direitos, ou, de modo mais explícito, são dispositivos que garantem a permanência em seus territórios.

$\mathrm{O}$ argumento de que os modos de vida desses grupos são compatíveis com a proteção ambiental não pressupóe, contudo, evocar o mito do bom selvagem, isto é, a ideia de que eles são naturalmente conservacionistas. Trata-se, antes, de reconhecer que povos e comunidades tradicionais exibem práticas culturais compatíveis com a conservação sem necessariamente explicitarem uma ideologia conservacionista: "seguem regras culturais do uso dos recursos naturais que, dada à densidade populacional e o território em que se aplicam, são sustentáveis" (Almeida, 2009, p. 288).

Isso nada tem a ver com uma essencialização ou naturalização dessas culturas, o que findaria por confiná-las no tempo, contrariando suas dinâmicas e as mudanças que vivenciaram ao longo de sua existência e por meio das relaçóes que estabeleceram com outras populaçóes de fronteira (Cunha, 2009). Assim, a incorporação de práticas e artefatos modernos, e mesmo a aproximação com as economias de mercado, como no caso das comunidades da Flona Tapajós, não significa necessariamente que seus modos de vida não são compatíveis com os limites biofísicos da natureza.

Esse deveria ser um pressuposto das negociações entre as comunidades que habitam territórios destinados à proteção ambiental e os operadores da conservação. Se as comunidades se ressentem das restriçóes que lhes foram impostas, é porque, de fato, raramente há um esforço dos representantes do Estado em compreender a dinâmica social, eco- nômica, cultural e ambiental que configurou aquela paisagem e as formas de uso que, apesar de terem sido "modernizadas", se mostram sustentáveis. Como sugere Lacey (2012), ao tratar da relação do mútuo reforço entre a sociodiversidade e a agrobiodiversidade, o fato de os processos de auto-organização da natureza terem sido mantidos indica a sustentabilidade dessas práticas submetidas ao teste do tempo.

\section{A sustentabilidade dos modos de vida das comunidades caboclas}

Ao assumirem estrategicamente a "identidade genérica” de povos e comunidades tradicionais, as populaçôes locais visibilizam politicamente suas singularidades e demarcam seus lugares de enunciação: suas paisagens, relações afetivas, memória coletiva, bens naturais disponíveis, formas de manejo e sistemas de uso comum. A despeito das controvérsias que o conceito evoca, ele tem servido ao propósito de preencher uma suposta lacuna identitária que é, claramente, fruto de nossa incapacidade de tradução e compreensão desses outros mundos, sistemas de vida e saberes estranhos à racionalidade da conservação.

Justamente por ser ampla, essa categoria é permanentemente entendida como sendo ressemantizada por grupos que, historicamente invisibilizados, ousam agora reivindicar designação territorial e o direito de se autonomear (Castro, 2013). Essa postura se expressa também na emergência de novas reivindicaçóes. Ao apontarem os limites dos modelos atuais das unidades de uso sustentável, inicialmente pensadas para seringueiros, indígenas e quilombolas, traduzem a necessidade de formas de designação territorial, zoneamentos e planos de manejo mais compatíveis com as condutas de territorialidade praticadas por diferentes povos e comunidades tradicionais (Nogueira, 2017). Sendo assim, a identidade PCTs funciona como uma categoria jurídica genérica, isto é, como uma identidade legalmente constituída em torno da defesa de interesses comuns, mas dentro da qual se expressa uma enorme diversidade territorial e identitária.

A situação dos caboclos da Flona Tapajós pode ser analisada à luz desses elementos. Sendo portadores de uma identidade supostamente precária 
ou no "meio do caminho", o discurso da gestão da unidade evoca clara suspeição quanto à sua "vocação ecológica". As falas dos gestores sugerem que as "comunidades precisam aprender a manejar a natureza corretamente", o que pressupóe que suas práticas ancestrais são equivocadas e que, portanto, não comunicam um modelo de sustentabilidade crível ou que se deva levar a sério para colocar em movimento uma "verdadeira conservação". Ainda que, e isso é um dado factual, a floresta esteja de pé porque eles sempre estiveram lá.

Estigmatizados também pelo histórico "determinismo ecológico que condena sua economia prémercantil de caça, extrativismo e pesca ao atraso, e apontados como sociedades predadoras que constituem empecilhos à conservaçáo da biodiversidade" (Nugent, 2006, p. 38), os caboclos ribeirinhos parecem não servir nem ao projeto desenvolvimentista, nem às políticas conservacionistas. São vistos como que condenados a um limbo identitário: não são índios, embora descendam diretamente deles. Descendem também dos neocamponeses (soldados da borracha e nordestinos que vieram em busca de ouro) e dos sulistas convocados a ocupar o "vazio demográfico da Amazônia” (Reis da Silva, 2015).

Além disso, conformam modos de vida "não necessariamente estipulados pelas convençôes da sabedoria herdada" (Nugent, 2006, p. 40): associam práticas indígenas (pesca, caça, coleta, extrativismo e roçado de mandioca), criação de gado e de animais de pequeno porte (galinha, porco, pato) e comercializam seus produtos (farinha, artefatos de palha, extrativismo) nos mercados das proximidades (Reis da Silva, 2015).

Não por acaso, as medidas de conservação, entre elas as limitaçóes para caça, pesca, extrativismo, espaços destinados aos roçados e seus respectivos tamanhos, comércio de excedentes, criação de gado e de porco, são, para essa população, o que Nugent (2006) chama de ônus da autenticidade. Uma população que comercializa o excedente de sua farinha e de seu pescado, que comercializa seu extrativismo, que tem parentes na cidade, que cria gado e porco, deve ser considerada tradicional e autêntica? Deve, portanto, ser aceita como aliada da conservação ou tratada como predadora e empecilho em potencial das políticas de proteção ambiental?
Observando a paisagem social e ambiental dos sitiantes dessa região, é bastante razoável pensar, como sugere Nugent, que "a inclusividade da identidade cultural amazônica é generosa”, pois permite múltiplas heranças (indígena, quilombola, nordestina, sulista) e a associação de diferentes práticas (criador, coletor, pescador, agricultor, produtor de farinha). É isso, portanto, que escapa à compreensão dos gestores da conservação.

As muitas diversidades de formas de amazoneidade - de possibilidades caboclas - são uma proteção contra a tendência de reificação de uma categoria estereotipada e intermediária de caboclo, residindo vagamente entre o índio precariamente situado e o cidadáo plenamente modernizado do futuro (Idem, p. 43).

Hoje, para além da antiga tentativa de tipificação da cultura cabocla, mostram-se mais adequadas as análises que buscam compreender as dinâmicas de ocupaçáo da terra e de uso dos bens naturais das sociedades históricas da Amazônia (suas práticas cotidianas, seus processos identitários, seus sistemas sociais, econômicos e ecológicos) no contexto das questôes políticas e ambientais mais amplas. Sendo assim, o que os operadores da conservação parecem insistir em não reconhecer é que

[...] há mais do que "necessidades básicas" de geração de renda e de provisão de alimentos no uso e manejo contínuos de habitats, ecossistemas e espécies protegidas em reservas, por parte dos grupos sociais nativos dessas áreas. Caça, pesca, coleta e agricultura itinerante, enquanto práticas, articulam-se a inúmeras outras dimensóes da vida social desses grupos e estão investidas de valores outros, e de uma importância que não é só de subsistência (Barreto Filho, 2006, p. 118).

Nessa direção, seria razoável considerar, como muitos autores têm afirmado, que a biodiversidade hoje encontrada nos ambientes naturais (sociais) amazônicos é resultado das históricas e complexas interaçôes entre forças físicas, biológicas e sociais (Almeida, 2009; Diegues, 2004; Descola, 2001). 
No mínimo, isso permitiria supor que os distúrbios autoproduzidos pela natureza e as perturbaçóes provocadas por grupos humanos tradicionais são, proporcionalmente, compatíveis com o que as ciências biofísicas chamam de capacidade de suporte e resiliência dos ecossistemas.

Trazendo essa questáo para o nosso debate, a experiência com sociedades tradicionais contemporâneas atesta que, apesar das mudanças pelas quais muitas delas passam ao longo do tempo, seus modos de vida e práticas de manejo demonstram forte capacidade de manter a floresta em pé. Essa capacidade de manutenção é quase sempre comprometida quando interesses econômicos avançam sobre seus territórios. Esse pressuposto, por assim dizer, aplica-se ao contexto e à história dos caboclos ribeirinhos da Flona Tapajós.

Sendo assim, não se trata necessariamente de provar que eles são os "herdeiros intelectuais do conhecimento ecológico indígena" (Barreto Filho, 2006, p. 119). Embora reconheçamos que efetivamente o são, trata-se, sobretudo, de admitir que seus hábitos, dietas, arquitetura, utensílios, ritos, tempos, enfim, suas práticas e seus saberes, ainda que multirreferenciados, oferecem importantes contribuições para a construção de alternativas de conservação aliadas a um desenvolvimento local socialmente justo e ecologicamente sustentável.

Indo além, isso se aplica aos modos de vida dos caboclos ribeirinhos da Flona Tapajós também porque, apesar de ter sido historicamente acossada pela presença ostensiva de madeireiros, fazendeiros, grileiros, barcos pesqueiros e, mais recentemente, pela agroindústria e monocultura da soja, essa população soube manter relaçóes de mútua cooperação, respeito e generosidade com os sistemas de vida (humanos e não humanos).

A identidade de caboclo ribeirinho desempenhou aqui um papel ambíguo. Estranha aos operadores da conservação, ela foi muitas vezes negada justamente por "não expressar marcadores étnicos claramente situados (indígenas e quilombolas)". Não obstante, a eminente perda do território, reforçada pela suspeição do pertencimento à tradiçâo, acabou por visibilizar as finas relaçóes entre seus modos de vida e a conservação, garantindo-lhes o direito de ficar - o que revela, no sentido mais amplo, que iden- tidade e luta pelo território engendram importantes processos de mútuo reforço.

\section{O direito de ficar e o desbotamento dos modos de vida}

Para as comunidades da Floresta Nacional do Tapajós, a permanência na unidade não resultou, necessariamente, no reconhecimento da sustentabilidade de suas formas tradicionais de manejo, o que se traduziu na adoção de restriçóes de uso e, em consequência, no acionamento de medidas que visavam amenizar o impacto das restriçóes sobre a vida da população. Em trabalho de campo, observando a vida cotidiana, a paisagem social e as atividades desenvolvidas pelas comunidades; ouvindo as queixas dos moradores e os seus silêncios, analisando as convicções dos profissionais responsáveis pela gestão da unidade, uma primeira constataçáo me parecia inevitável: o direito de ficar cobrou seu preço, o abandono silencioso e progressivo das antigas práticas.

A seguir, destaco algumas das situaçóes narradas por moradores, privilegiando as que considerei mais relevantes para a reflexão empreendida aqui. Busco, neste primeiro momento, apenas indicar os aspectos selecionados para, na sequência, analisar seus efeitos sobre os modos de vida. Isto é, os efeitos do tensionamento entre a "razão instrumental do Estado" (regras, controle e planejamento da conservação) e a "razão histórica dos povos e comunidades tradicionais" (suas cosmografias, regimes de propriedade comum, relaçôes afetivas com o lugar, memórias coletivas) (Little, 2002, p. 259).

Uma queixa recorrente entre os moradores diz respeito à forma como as mudanças foram sendo introduzidas e percebidas na vida cotidiana. O processo de negociação envolveu uma série de encontros, reuniôes, consultas e audiências públicas. A definição das regras implicava um intrigado processo de negociação com as comunidades, e isso se dava sem que se tivesse definido, por exemplo, a situação das famílias assentadas do Incra e das comunidades Marituba, Bragança e Taquara que, desde 1997, passaram a se autoidentificar indígenas e a reivindicar demarcação de uma área dentro da Flona (Ibama-MMA, 2004). Também é importan- 
te lembrar que, diferentemente de outras categorias de unidades de uso sustentável, como as reservas extrativistas, por exemplo, as Florestas Nacionais não contam com um conselho deliberativo, apenas com um conselho consultivo. Isso significa, em última instância, que, apesar de estar prevista a representação das associaçóes comunitárias e intercomunitárias e da sociedade civil, as expectativas, desejos e aspiraçóes da comunidade contam, mas não decidem. A esse respeito, alguns moradores afirmam que as regras que constam do termo de concessão e uso não foram as mesmas acordadas entre as comunidades e o ICMBio. Isto é, o combinado teria ganhado outra redação no documento final. Outros dizem que só entenderam o que essas mudanças representavam quando as advertências e multas do ICMBio começaram a chegar, que assinaram o termo sem ler, na confiança de que o que havia sido negociado verbalmente estaria escrito no papel. $\mathrm{Ou}$, ainda, como destaca um dos moradores: "em alguns casos, o representante da família (mãe, pai, filho mais velho, avô ou avó) não leu porque é analfabeto" (Comunitário 1).

As falas registram que o zoneamento oficial instituído na unidade modificou profundamente o zoneamento convencionado pelas práticas comunitárias. Os roçados foram proibidos nas áreas de mata, de solo fértil, e ficaram restritos às áreas de capoeira, que são clareiras abertas ao redor das casas ou em áreas próximas aos rios, constituindo terrenos arenosos, de baixa fertilidade. Em pouco tempo, a maioria das famílias deixou de roçar. A restrição do tamanho "não compensava mais" e os roçados, agora restritos à capoeira, "não era mais certeza que dava” (Comunitário 1).

Assim, as famílias passaram de produtoras a consumidoras de farinha. O produto ficou escasso, a farinha sumiu, o preço subiu, e o que era produto farto e certo, que muitas vezes gerava alguma renda para as famílias, virou necessidade básica, que demandava a posse de dinheiro. Ademais, a farinha não é apenas um componente imprescindível $\mathrm{da}$ dieta alimentar das populaçóes caboclas da Amazônia, pois, como se diz por essas paragens, "pode faltar o peixe, mas não a farinha”. A farinha simboliza muitas dimensóes da vida comunitária e está presente em diversos momentos de reciprocidade.
Ela é um agrado que se dá a um parente ou a uma visita, é uma poupança, uma importante moeda de troca, um elo de aproximaçáo dos comunitários que se reúnem em mutiróes para plantar a mandioca e fazer a farinha:

Farinha? Era o que mais se fazia! Era a nossa produção [...]. Era muito importante você ter e chegar aqui: "olha eu não tenho farinha pra comer”. Então pega um pouco de farinha! E dá pra eles comer. [...] Antes a gente se reunia pra fazer o roçado, mutirão, reunia tudo, depois dividia a farinha. E quando alguém não tinha farinha era quem mais queria dar um pouco. Hoje quando a gente enxerga de longe um parente chegando já sai escondendo a farinha. Porque tem pouco, né!? (Comunitário 2).

A farinha que sumiu era uma das dimensóes materiais e imateriais que se tinha em abundância: "a nossa produção" coletiva da existência, aquilo que motivava a "reuniâo", que forjava em todos, e em cada um, gestos cotidianos de solidariedade. Essas ausências não podem ser reparadas por benefícios sociais, como o Bolsa Verde, ${ }^{7}$ que, rapidamente, se transformou numa compensação financeira em razão da diminuição substantiva da produção da farinha. Não podem ser reparados porque seus efeitos não estão relacionados com a penúria material, isto é, não se trata de matar a fome.

Em sentido mais amplo, a criação da unidade afetou de forma profunda a relação das comunidades com as áreas de mata que foram, historicamente, de suma importância para reprodução material e imaterial da cultura cabocla da Flona Tapajós (Lins e Silva, 1980). Além de proverem alimentos (caça, frutos e farinha), essas áreas são guardiâs de plantas medicinais, de produtos florestais usados na construção de moradias e artefatos (canoas e remos) e de uma variedade de produtos não madeireiros (breu branco, breu preto, barro, cipó titica, andiroba, copaíba etc.) manejados para o consumo familiar e como fonte de renda. Eram também nessas áreas de mata (áreas de planalto) que as comunidades estabeleciam seus sítios: roçados, casa de farinha e moradias para serem habitadas no período da cheia, quando a subida das águas alcançava as áreas de baixa (perto do rio) (Ioris, 2000). 
Essa dinâmica da vida participava de modo decisivo da conformação de um modelo particular de cultura/natureza (Escobar, 2010): de um jeito de se relacionar com o mundo natural, que gerava formas singulares de manejos e saberes. Com efeito, para além das questóes ligadas à sobrevivência, o que se perde nesses processos são ritos fundamentais à manutenção dos laços de solidariedade, do sentimento de compartilhamento da vida, dos meios de sobrevivência, do universo simbólico e da memória coletiva. São, portanto, uma série de relaçóes sociais, produtivas e culturais que simplesmente se desfazem quando as condiçóes materiais da existência que as originam são alteradas.

\section{Ecoturismo comunitário: entre ganhos e derrotas}

Além do Bolsa Verde, outra medida acionada foi o ecoturismo comunitário associado à produção de artesanato com produtos florestais madeireiros e não madeireiros. Como se sabe, essa atividade é frequentemente estimulada por ser considerada uma forma eficiente de gestấo da conservação, que gera renda sem alterar ou comprometer a dinâmica dos ecossistemas. O princípio que motiva sua adoção pressupóe o ecoturismo como uma estratégia de desenvolvimento local aliada à conservação (Portuguez, Seabra e Queiroz, 2012).

A ideia de que as atividades contemplativas (lazer e turismo) causam menos impactos do que as atividades tradicionalmente desenvolvidas pelas populaçôes locais e deveriam, por isso, substituí-las progressivamente, remonta à criação das primeiras áreas protegidas do país (Pádua, 1979). Contudo, também no contexto mais recente, essa atividade conta com forte adesão e, não raro, é colocada no rol das açôes que deveriam ser priorizadas nas verdadeiras áreas protegidas que precisam ser "adequadamente manejadas e aproveitadas para o desenvolvimento do turismo" (Pádua, 2011, p. 28). ${ }^{8}$

$\mathrm{Na}$ Flona Tapajós, apenas três das dezenove comunidades desenvolvem atividades de ecoturismo com certa regularidade. Entre essas, há uma que se destaca, pois a atividade assumiu um lugar importante na produção da renda familiar. A comunidade conta com trilhas, mateiros da própria comunidade que trabalham como guias turísticos, um pequeno espaço onde é comercializado o artesanato local, pequenos comércios (mercearias), pousadas bem simples, mas que oferecem redários e refeiçóes. A vida comunitária gira bastante em torno do turismo, sobretudo na alta temporada (período da vazante), quando provavelmente é garantido o provimento financeiro das famílias, já que, no período da cheia (subida das águas), os turistas desaparecem. Segundo os próprios moradores, não há mais tempo para dedicar ao roçado e à pesca, pois os turistas ocupam todo tempo de que dispóem.

As famílias mais envolvidas com a atividade exibem um destacado poder aquisitivo em relaçáo às demais: moram em grandes casas de alvenaria, dispōem de utensílios domésticos modernos, luz elétrica, água encanada. Esse poder aquisitivo, é importante que se diga, não é proveniente apenas do turismo. Essas famílias também participam ativamente em outro empreendimento da unidade, $o$ manejo florestal em larga escala, sobre o qual tratarei mais adiante.

Segundo um dos moradores dessa comunidade, a melhora do poder aquisitivo foi uma das coisas boas que a Flona trouxe: "a vida melhorou". Até porque, ele complementa: "quem disse que a gente tá condenado a passar o resto da vida pelejando na roça. A gente também quer dignidade" (Comunitário 3). De fato, a lida na roça é penosa, e, muitas vezes, dedica-se uma parte considerável do tempo diário às atividades que visam suprir as necessidades mais imediatas da vida. É, portanto, compreensivo que se aspire a uma vida com mais conforto e comodidades, que se deseje mais tempo para dedicar a outras dimensóes da existência.

Contudo, a questáo não se coloca efetivamente nesses termos. Insisti com meu interlocutor sobre a possibilidade de se "modernizar" a forma de fazer o roçado e de produzir a farinha para que a prática pudesse ser valorizada e mantida na comunidade sem exigir o "sacrifício físico e do tempo". Obtive respostas negativas veementes e longos silêncios: "as pessoas idealizam nossa vida, mas não é bem assim (silêncio)" (Comunitário 3).

O que se observa é que outras lógicas de tempo e de produção da existência começam a assumir um papel importante nessas comunidades. A presença sutil de um discurso que nega qualquer compatibili- 
dade possível entre o antigo jeito de viver e uma vida menos penosa sugere que a roça não combina com uma “vida mais moderna”. Logo, é preciso reinventar o jeito de viver, incorporando formas "mais civilizadas" de sobrevivência. Essa visão, aliás, é bastante compatível com a ideologia da inclusão pelo consumo de bens e serviços que orientou importantes políticas sociais dos últimos dezesseis anos.

Seria ingênuo demonizar esse caminho como uma forma viável para combater a desigualdade e promover a justiça social. Não obstante, é preciso também reconhecer que a adoção desse caminho como única via possível pode nos levar a um incontornável desperdício de experiências, de modos de vida e de seus saberes associados, à inviabilização de outras formas de existência e à colonização de outros mundos possíveis que fazem um contraponto ideológico importante ao desenvolvimento hegemônico baseado, exclusivamente, no progresso científico e tecnológico (Santos, 2005). Essa perspectiva monocultural do tempo e dos saberes tem se mostrado, cada vez mais, como um caminho empobrecedor que, por sua lógica impositiva, deixa um rastro de extermínio, de etnocídio, de ecocídio, de violências físicas e simbólicas.

Nesse sentido, um morador de outra comunidade onde o ecoturismo não é tão presente contesta veementemente a visão de que as novas práticas melhoraram a vida:

As pessoas deixaram de trabalhar, de roçar pra andar com turista. [...] um dia desses chegou um cara aqui: "queria que fosse lá". Eu disse: rapaz cê tá doido, tá maluco? Tu acha que eu vou perder meu tempo pra te mostrar uma caverna? Num vou não, deixa lá. Isso aí é obra da natureza, ficou aí pra gente conhecer, ficou sim, um dia a gente conhece, mas num é assim, toda hora, ficar fazendo inventário das coisas, indo lá e voltando todo tempo. Naquela época não entrava turista, hoje em dia é o que mais entra. Esse tal de ecoturismo comunitário dá dinheiro? Dá! Mas dá derrota também (Comunitário 4).

Aqui a terra é valorada pelo papel que desempenha na produção da existência: um valor que se materializa na lida para a garantia do sustento. Essa dimensão material, gestada pelo trabalho no seu sentido positivo, participa também da conformação das dimensôes simbólicas da vida: o valor e o lugar da natureza, do dinheiro, da derrota, do trabalho. Logo, o ecoturismo, que vai, pouco a pouco, ocupando o lugar da lida com a terra, é visto como trabalho no seu sentido negativo: o não trabalho, a derrota. Desse ponto de vista, não se trata de melhorar de vida, mas, antes, de suspender a produção da existência para atender às necessidades de outrem (o turista). Assim, a vida, em suas dimensóes materiais e simbólicas, é, desse ponto de vista, subalternizada e colonizada por valores e necessidades estranhas à comunidade.

Para esse morador, tudo isso faz parte de uma ideia que vem sendo inculcada pelo ICMBio: "eles incentivam os moradores a acreditar que lá fora é melhor do que aqui dentro, que, se parar de roçar, caçar ou pescar, eles terão outras oportunidades: Bolsa Verde, emprego" (Comunitário 4). Essa seria uma estratégia meticulosamente arquitetada e empreendida para fabricar um projeto de vida em que o "lá fora", ou as coisas do mundo lá fora (emprego, dinheiro, bens de consumo), dialoga mais com a ideia de "progredir na vida", "melhorar de vida”, enquanto o "aqui dentro" e as antigas formas de produzir a existência vão se tornando cada vez mais pueris, coisa de um passado atrasado, de uma vida difícil que se quer deixar para trás. Por mais absurda e inverossímil que possa parecer essa interpretação, é fato que, por conta do dinheiro que vem "fácil", que chega com os turistas ou pelo Bolsa Verde, comunidades inteiras deixam de roçar e estão, pouco a pouco, se transformando em "nativos a serviço dos visitantes".

O fato de o ecoturismo ser desenvolvido por poucas comunidades indica, também, que essa prática possui dificuldade de se legitimar diante da populaçáo local, o que pode estar ligado à progressiva fragilidade da organização e participação comunitária e intercomunitária no planejamento de estratégias para desenvolvimento local. É o que comenta, com saudosismo, um dos moradores:

Antes a gente sabia reunir as pessoas pra resolver os problemas de todos. Agora náo tem mais 
estímulo. Chamam a gente pra ir reunir lá em Belterra. Longe da comunidade. Eu não vou. A gente olha para o passado e vê que tá tudo diferente: o companheirismo, o respeito, o extrativismo, a produção, tudo (Comunitário 5).

Essa é uma das questóes mais delicadas da gestấo de unidades de conservação que contam apenas com conselho consultivo: garantir a autonomia e a participação ativa das comunidades nos processos de decisão e de escolha de um caminho de desenvolvimento local que seja, de fato, uma aspiração construída coletivamente e condizente com seus valores, cosmografias, regimes de uso e formas de manejo. Aqui, as formas comunitárias de debater e encontrar soluçóes coletivas para os problemas comuns foram substituídas por uma participação representativa com assentos no conselho consultivo. Ao se delegar a um representante, mesmo que ele seja da comunidade, o poder de falar e propor em nome do coletivo, os dilemas deixam de ser problemas de todos, assim como as possibilidades de resolução vão ficando cada vez mais lá fora, longe da comunidade.

\section{Manejo florestal sustentável em larga escala: uma contradição entre termos}

Uma terceira prática adotada na comunidade e que, por diversas razóes, merece dar atenção é o "manejo florestal de caráter empresarial". O manejo florestal realizado por empresas privadas já ocorria na unidade, antes mesmo de se ter uma definição sobre o destino da população local, por intermédio de concessóes do Instituto Brasileiro do Meio Ambiente e dos Recursos Naturais Renováveis (Ibama), no âmbito dos Projetos Promanejo e Itto/Iba$\mathrm{ma}$, que pretendiam diminuir a exploração ilegal da madeira na Amazônia brasileira. ${ }^{?}$

Instituída a unidade, os gestores iniciaram um processo de convencimento das comunidades para reivindicar o direito de exploraçáo exclusiva dos recursos madeireiros. Projetava-se, ademais, que, além de fazer justiça socioambiental, a atividade poderia cumprir um papel importante na mitigação dos impactos das novas regras de uso sobre os meios de produção das famílias. A saída encontrada foi o reagrupamento das associaçóes comunitárias em associações intercomunitárias - Asmiprut, Aita, Aprusanta - que permitiu, em 2005, a criação da Cooperativa Mista da Flona Tapajós (Coomflona) (Bicalho e Hoefle, 2014).

Algumas avaliações acerca dessa experiência são bastante otimistas em relaçáo à sua natureza e, em geral, exibem dados muito positivos que findam por indicá-la como uma "prática de manejo florestal sustentado, ambientalmente responsável, lucrativa, com forte capacidade de geração de renda e inclusão social" (Bicalho e Hoefle, 2014; Bacha e Rodriguez, 2004). Essa visão sintetiza o discurso que se tem propagado, inclusive pelo próprio ICMBio, que divulga o manejo florestal da Flona Tapajós como um exemplo bem-sucedido de conservação, aliado ao desenvolvimento local sustentável. Essa positividade também aparece nas falas dos comunitários que são cooperados, contradizendo, contudo, a avaliação feita por aqueles que não são cooperados e que não usufruem diretamente dos lucros da cooperativa. Tendo a ponderar, com esses, que, onde a lógica de mercado se instala, as relações de reciprocidade vão tomando feiçôes individualistas, convertendo-se em disputas, hierarquias e desigualdades.

Algumas particularidades desse empreendimento, já sob a gestão das comunidades, merecem nossa atenção. A primeira e mais evidente é a flagrante contradição entre os termos que definem a natureza da atividade: manejo sustentável em caráter empresarial (ou em larga escala). Ora, o manejo sustentável se dá - justamente por sua particularidade e diferentemente do empresarial - em baixa escala, e sua gestáo via cooperativa deveria objetivar, ao menos em tese, formas mais justas de acesso aos recursos disponíveis (inclusive dos florestais não madeireiros) e não a rentabilidade.

Não obstante, esses dois aspectos, a escala e a lucratividade, são, ao que parece, as razóes da atmosfera de otimismo que gira em torno dessa experiência. A ênfase nos recursos madeireiros é, segundo os profissionais que assessoram a cooperativa, "um mal necessário". Isso porque o retorno financeiro é certo e imediato: "sempre haverá clientes em busca de madeira, sobretudo da Amazônia, de populações tradicionais e com selo verde" (Entrevistado 2). Trata-se, segundo eles, de um empreen- 
dimento que náo sobreviveria fora das regras do mercado, logo, tal como em uma empresa, a cooperativa também precisa garantir:

Produtividade e eficiência da produção: atrativo ao mercado; retorno financeiro; ampliação da capacidade de mercado. Evitar desperdício: produzir o máximo que a máquina permitir em 8 horas. Se o trabalhador é pago por oito horas, então ele precisa produzir por oito horas, até porque tem o custo da alimentação (Entrevistado 3).

Mirando esse cenário, comunitários não cooperados oferecem uma leitura menos otimista. Para eles, "a Coomflona virou um lugar de privilégios, onde só entram para serem cooperados os parentes e amigos dos presidentes das comunidades" (Comunitário 6). Os benefícios coletivos, a parte comum do dinheiro que é compartilhada entre as comunidades para melhoria das estradas vicinais, por exemplo, não é para muitos uma forma justa de distribuição do lucro. Além disso, o acesso real aos valores produzidos pela cooperativa - seja mediante salário ou cota-participação nos lucros - gerou uma hierarquia social entre os moradores: entre aqueles que estão prosperando, se dando bem, e aqueles que anseiam chegar a esse lugar um dia. Por ter se tornado uma importante fonte de renda, associada ao fato de que nem todos chegarão a ser cooperados, essa medida, que visava garantir uma vida melhor para todos, desencadeou uma série de conflitos, desagregações, disputas, hierarquias e relaçóes de poder.

Observe-se, ainda, que os comunitários que trabalham nas diferentes etapas do manejo (inventário, derrubada, romaneio, administração etc.), e recebem salário por isso, comportam-se, muitas vezes, como trabalhadores/assalariados e não necessariamente como cooperados. Em uma das minhas visitas, uma situação de atraso no pagamento das cotas e dos salários gerava entre os manejadores uma deflagração de greve. Estes se referiam ao presidente da cooperativa, igualmente comunitário, como o patrão.

À medida que a cooperativa cresceu, que o dinheiro começou a entrar, que o negócio começou a se expandir, aumentou o interesse dos não coope- rados em tomar parte no empreendimento. Ocorre que - essa foi uma das explicaçóes ouvidas - não seria possível colocar toda a população como cooperada porque nem todos apresentam habilidades e competências para as atividades exigidas, o que findaria por gerar uma relação desigual na divisão das cotas, já que elas são mensuradas pelo tempo e pelo tipo de trabalho dedicado na gestão da cooperativa e no manejo. Além disso, em uma situação suposta de que todos viessem a ser cooperados, as cotas de participação ficariam muito pequenas e a cooperativa deixaria de ser atrativa. Para resolver a questão de forma coletiva, os cooperados aprovaram em assembleia um requisito básico para a entrada de novos membros: ter, pelo menos, o ensino fundamental completo. Essa medida impedia, por exemplo, que os moradores mais velhos, militantes históricos atuantes desde 1974, que fundaram a cooperativa, entrassem ou permanecessem como cooperados.

A busca por uma alternativa viável de desenvolvimento sustentável tomou, aqui, um percurso inverso à sustentabilidade ecológica informada pelos modos de vida dessas comunidades, a tal ponto que, ao invés de colaborar para sua visibilização e fortalecimento, acaba por condená-las ainda mais ao estigma de um modo de vida predatório e atrasado, que não serve nem ao desenvolvimentismo, nem à conservação. Trata-se, quando muito, de um desenvolvimento local sustentável fortemente coerente com os pressupostos da economia verde, que acionam saídas de mercado em contextos onde, há pouco tempo, prevaleciam regras muito mais inclusivas e generosas (Almeida, 2012).

As estratégias oficiais que tomam lugar na Flona Tapajós, que pretendem gerar renda e mitigar os impactos das restriçóes sobre a produção da existência, compóem um cenário pouco otimista de progressivo esquecimento das antigas práticas, individualismo, conflitos e disputas derivadas dos novos arranjos econômicos, disparidades das condiçôes de vida, comprometimento dos laços comunitários e dos arranjos sociais baseados na solidariedade.

Náo se trata de ser contra medidas compensatórias, que, em muitos casos, são de suma importância para restabelecer a capacidade de produção da existência. Todavia, "o planejamento de áreas protegidas sensível à dimensão cultural” parece muitas vezes 
visar mais "à harmonização de conflitos e às assimetrias" do que à efetiva incorporaçáo dos modos de vida tradicionais como importantes aliados da conservação da biodiversidade (Barreto Filho, 2006, p. 166). Em tese, as populaçóes locais podem contar com um instrumento jurídico importante para a defesa de seu território: as unidades de uso sustentável. Na prática, o zoneamento das áreas protegidas - mecanismo administrativo destinado a ordenar e regular a apropriação do espaço - finda por "enquadrar a diversidade cultural nos desígnios da conservação" (Idem, p. 113).

Nesse sentido, a avaliação de um morador mostra como, ao apaziguar os conflitos entre o Estado e a população ameaçada por um eminente despejo, a garantia do território provocou um refluxo na mobilização comunitária: "quando todo mundo estava ameaçado, nós era unido; depois que a ameaça passou, chegou o chefe e foi cada um pro seu lado. Isso aqui não é mais nosso, nós podemos até morar aqui, mas não é mais nosso" (Comunitário 7).

O direito de ficar, como é possível constatar, pode ser silenciosamente violento. Admitindo-se, como sugere Little (2002, p. 3), que a territorialidade constitui um "esforço coletivo de um grupo social para ocupar, usar, controlar e se identificar com uma parcela específica de seu ambiente biofísico", as restriçôes e compensações não apenas alteram o cotidiano das comunidades locais, mas podem se traduzir, ao longo do tempo, no esquecimento dos modelos de natureza que conformaram suas identidades e pertencimentos (Escobar, 2010).

Seguindo essa lógica, parece razoável supor que, em tais contextos, a população local esteja submetida a processos de desterritorialização dos seus modos de vida, o que configura uma forma de territorialidade precária, que se dá não pela negação das condiçóes de reprodução material e imaterial da existência, mas sim pela proibição de determinadas formas de uso e manejo e pela inserção de outras práticas e de mecanismos econômicos compensatórios que vão tomando o lugar do antigo jeito de viver.

Não estamos sugerindo, evidentemente, nem uma "(des)territorializaçâo absoluta, nem a desterritorialização no sentido da perda de acesso à terra e aos meios de reproduçáo material e lócus de apropriação simbólica” (Haesbaert, 2004, pp. 17-18).
Trata-se de um processo estranhamente inverso: garante-se a territorialidade física enquanto se modifica (desterritorializa) o jeito de viver. A (des)territorialização e a (re)territorialização, o que Haesbaert chamou de duas faces de um mesmo processo, apresentam-se aqui nos seguintes termos: à medida que as restriçôes e compensações vão se estabelecendo no cotidiano, o antigo jeito de viver vai dando lugar a novas práticas. Apresentadas como formas negociadas de cogestão da unidade, elas são, na verdade, condiçóes para permanecer no território.

Aqui, o desbotamento dos modos de vida impóe a conformação de outras condutas de territorialidade (Little, 2002): ecoturismo, manejo em larga escala, trabalho assalariado etc. Uma nova e precária territorialidade dos modos vida: nova porque conforma meios de sobrevivência estranhos, isto é, não familiares às comunidades; precária à medida que desmantela as antigas práticas, fadando-as ao desaparecimento.

Segundo Diegues (2008), as práticas de manejo desenvolvidas pelas populaçôes tradicionais envolvem, correlatamente, modelos de natureza, relaçóes socioculturais e modos específicos de territorialidade. Assim, "uma porção da natureza e do espaço que uma sociedade determinada reivindica" (Diegues, 2008, p. 83) pressupóe direitos de acesso, controle ou uso dos recursos naturais aí existentes, isto é, aquilo que Godelier (1974) chama de meios de subsistência, meios de trabalho e produção, meios de produzir os aspetos materiais das relaçóes sociais, aqueles que compóem a estrutura determinada de uma sociedade, relaçôes de parentesco etc.

Contudo, como um processo continuum de dominação e/ou apropriação, o território comporta múltiplas manifestações em razão dos agentes/sujeitos que o reivindicam e/ou acionam, sejam eles indivíduos, grupos sociais, Estado, empresas, instituições (Haesbaert, 2004). Logo, ainda que não corresponda ao debilitamento do espaço, a (des)territorialização pode estar associada, "em maior ou menor intensidade, à dinâmica econômica que dilacera os espaços, subordina poderes políticos e condiciona (quando não direciona) a reformulação de muitas estratégias identitárias" (Haesbaert, 2003, p. 18).

Nesse sentido é que se pode compreender que as pressóes exercidas por outros grupos, no caso da 
Flona, pelo governo, moldam (e às vezes impóem) outras condutas territoriais. Até porque, nem sempre, o choque de condutas territoriais resulta em formas de resistência. Há também processos de "acomodação, apropriação, consentimento, influência mútua e mistura entre todas as partes envolvidas" (Little, 2002, pp. 4-5).

\section{Os contornos de uma "guerra ontológica": ampliando as perspectivas de análise}

As reflexóes de Almeida sobre a economia política da natureza e de entes não naturais, informados pelas experiências de manejo de caça desenvolvidas na Reserva Extrativista do Alto Juruá a partir de 1990, mostram-se profícuas para ampliar a análise dos desdobramentos da exploração da madeira na Flona Tapajós. Tendo ganhado centralidade na vida das comunidades aí residentes, podese pressupor aqui, assim como pressupóe Almeida no contexto do Alto Juruá, que essa prática evoca a coexistência e o tensionamento entre ontologias: "ontologias das coisas produzidas, ontologias dos entes naturais não produzidos, ontologias dos entes sobrenaturais não produzidos". Entendendo-se, como o próprio autor sugere, que "ontologias dizem respeito ao que existe", e ontologias sociais dizem respeito "aos entes sociais reconhecidos como existentes" (Almeida, 2013, p. 22), estamos tratando da existência de animais manejáveis para conservacionistas, de caiporas para caçadores, de boto que vira homem para pescadores, de árvores exploráveis para engenheiros florestais.

O manejo florestal em larga escala, assim como outras experiências desenvolvidas sob a égide da extração sustentável, tem sido documentado e analisado como um modelo científico capaz de conciliar eficiência ambiental e viabilidade econômica. Aliás, as controvérsias aí suscitadas quase sempre giram em torno dessa dupla capacidade anunciada: explorar extensivamente com altíssima eficácia gerencial e econômica (lucro) e, ao mesmo tempo, manter a floresta em pé. Se, para os defensores da ecoeficiência (Economia Verde), tal conciliação reforça o argumento de que é possível gerir os recursos naturais acionando tecnologias limpas, para os críticos dessa perspectiva trata-se de um caminho falacioso, pois associar exploração em larga escala e sustentabilidade constitui uma contradição entre termos (Reis da Silva, 2015).

Ocorre que, ainda que se logre conciliar extrativismo extensivo voltado ao mercado e sustentabilidade ecológica, em tais processos as pessoas (humanas e não humanas) só entram na equação como insumos (mão de obra e matéria-prima). Quase sempre suas relaçóes, saberes, práticas e modos próprios de coexistir náo são levados em conta, embora sejam essas as dimensóes que permitem considerar efeitos imateriais (intangíveis), isto é, aquilo que não pode ser contabilizado e que nem sempre é visível e/ou evidente.

A experiência de manejo de caça analisada por Almeida dá conta de uma complexa relação entre o que ele chama de ontologia da extração sustentável, ontologia caipora e ontologia da extração extensiva. $\mathrm{O}$ autor observa convergências entre a ontologia da extração sustentável - que opera com modelos matemáticos para garantir o equilíbrio entre a taxa de consumo e a capacidade de reprodução das espécies caçadas - e a ontologia caipora - cujo controle do estoque de caça é operado por caipora, em seu território, pela observância de uma "etiqueta obrigatória" que impóe interditos e estabelece regras que governam as relações entre humanos e não humanos. Embora "vastamente diferentes nas entidades que pressupóem" - naquilo que consideram como existente no mundo, caiporas/caçadores/caça de um lado, e modelagens de extração sustentável do outro -, ontologias da extração sustentável e ontologias caipora "podem ser confrontadas pragmaticamente". Isto é, podem ser compatíveis em termos de intencionalidade e de resultados, já que projetam a continuidade das relaçóes de coexistência entre culturas e naturezas - caças/caçadores (Almeida, 2013, pp. 18-20).

No caso do encontro entre ontologias caipora e ontologias da extraçấo extensiva, "trata-se de um ato de guerra ontológica". Justamente por prever "caçada comercial, produção e manejo da vida silvestre, transporte de animal vivo, processamento de carcaça e de carne e comercialização de produtos e subprodutos", o resultado pragmático consiste, segundo Almeida, em uma "subordinação da vida silvestre ao mercado", e, portanto, em rompimento 
dos interditos e das regras estabelecidas por caipora para a concertação de acordos e relações entre os mundos humano, natural e sobrenatural. Essas ontologias são absolutamente antagônicas.

Traçando um paralelo entre Alto Juruá e Flona Tapajós, o encontro entre ontologias extrativistas (que mercantilizam a floresta) e ontologias caboclas (supondo que elas existam e que agenciem povos humanos, entes naturais e sobrenaturais, cujas relaçóes são baseadas em interditos, sançóes e reciprocidades $)^{10}$ constitui um "ato de guerra ontológica, que destrói redes de vizinhança e coloca no lugar delas redes de mercado". O regime de mercado é incompatível com ontologias caiporas e ontologias caboclas "porque redes de vizinhança são incompatíveis com o sistema de mercado", uma vez que, para ontologias mercantilistas, "o pressuposto é que todo ente é conversível em dinheiro - o dinheiro é a textura que interliga todo e qualquer objeto". Em tais contextos, "não há diferença ontológica, mas destruição de uma ontologia por outra" (Idem, pp. 20-22).

Embora não esteja no horizonte deste artigo ${ }^{11}$ analisar em que medida a ontologia da mercantilização e da coisificação da floresta afeta as práticas tradicionais de manejo e os sistemas de valores da população tradicional que habita a Flona Tapajós, é possível ao menos supor que a presença cada vez mais ostensiva dessa lógica pode desencadear não apenas conflitos entre pessoas humanas (o que já se observa), mas também entre os entes de mundos contíguos (humano, natural, sobrenatural). Conflitos que, em consequência, alteram relaçóes historicamente baseadas em princípios de reciprocidade e regras próprias de coexistência.

Nesse sentido, deve-se considerar que a expulsão dos/as moradores/as também se dá pela privaçáo dos modos de vida (sistemas de valores, regras próprias e relaçóes entre humanos e não humanos), pois o que antes era livremente acessado pelas comunidades agora é gerido de modo a limitar o acesso à floresta. Esse constrangimento afeta os regimes de uso do território praticados historicamente e, consequentemente, as interaçóes entre os entes da floresta, seus donos (encantados) e as pessoas humanas (Wawzyniak, 2010).

Com a intensificação da exploração madeireira, a interação mais praticada hoje na Flona Ta- pajós reduziu a floresta a dados estatísticos, a um conjunto inventariado de espécies, cientificamente nomeadas. Árvores são transformadas em números, derrubadas como madeira em potencial, arrastadas como toras e comercializadas como mercadoria.

É particularmente chocante assistir à derrubada de uma árvore centenária. Há algo de incomensurável que se perde aí. Náo me refiro ao ato da derrubada em si, pois os caboclos da Flona, assim como outras sociedades tradicionais, também derrubavam árvores para construir seus jiraus, remos, canoas, botes, casas e pontes de acesso ao rio. Refiro-me, antes, à ostensividade do aparato e à frieza da técnica que envolve o processo de derrubada, não de uma, mas de muitas árvores que serão transformadas em commodities.

Ademais, para manejar determinados recursos para o consumo familiar (palha para cobertura da casa, madeira para construir um bote ou um remo), os habitantes são obrigados a solicitar autorização ao Ibama. Assim, a expulsão pode ser entendida, também, como anulação da autonomia das comunidades e cerceamento das relaçốes das pessoas com a floresta e seus encantados. Em lugar dessas relaçóes, emergem lógicas instrumentais: a gestáo externa (personificada na figura do chefe) e seus mecanismos de controle (limitaçóes e interdiçóes); a instalação da burocracia no coração de dimensōes fundamentais e essenciais à vida; a proliferação de processos de vigilância/punição (multas, barganhas, delações) no cerne das relaçóes comunitárias, intercomunitárias, interfamiliares e interpessoais.

\section{Consideraçóes finais}

Na Flona Tapajós, as restriçóes, os mecanismos de controle e as medidas compensatórias, muitas delas afinadas com a lógica do mercado, provocaram fissuras nos modos de vida e nas relaçôes comunitárias. Se antes elas eram orientadas, quase exclusivamente, por uma solidariedade horizontal, já que todos desenvolviam as mesmas atividades e viviam em condiçôes semelhantes, hoje são baseadas também em uma solidariedade vertical, induzida pela melhoria do poder aquisitivo de alguns (Santos, 2005). Isto é, as novas práticas econômicas não 
apenas produziram o abandono das antigas, mas também criaram distinçóes entre modos de vida e condições de existência.

Ao longo deste artigo, afirmei que "o direito de ficar tem des(re)territorializado os modos de vida". Isso diz respeito menos à permanência no território e mais à prerrogativa da população de decidir, de forma autônoma e esclarecida, se deseja existir segundo seus costumes, mantendo os laços, o modo de vida e os usos dos espaços que participaram historicamente na conformação de seus pertencimentos àquele lugar; se é hora de abandonar as velhas práticas e "modernizar" a vida na floresta; ou, ainda, se essas práticas podem coexistir e em quais termos.

Ora, se para alguns as mudanças não estavam claramente compreendidas, nem foram definidas de forma democrática e participativa, é preciso considerar as assimetrias de poder que atravessam as relaçóes entre Estado e PCTs. Não raro, o direito de opinar em assembleias e reunióes é sutilmente subalternizado pela autoridade do discurso e da posição de poder ocupada por aqueles que falam em nome da gestão pública e que têm a expertise da conservação: o chefe, que é de fora e é "doutor". $\mathrm{O}$ discurso investido de autoridade cumpre, muitas vezes, o propósito de relembrar à comunidade, a todo instante, que o silêncio, a aceitação e a resignação são estratégias mais "inteligentes” de garantir o direito ao território do que o questionamento e o enfrentamento.

Entre os comunitários, constatam-se posturas e avaliaçóes distintas sobre os novos meios de produção da existência e as mudanças que eles provocam. $\mathrm{O}$ que alguns identificam como avanços (o emprego, o salário, o turismo, o aumento da renda e do consumo), outros definem como derrotas. Esse é um elemento de fissura que pode comprometer a construção de projetos comuns e o sentimento de pertença, pois parece haver poucos pontos de convergência entre aqueles que são apontados como atrasados - porque seguem vivendo do roçado e da pesca e morando em casas de palha e madeira - e aqueles que veem no turismo, na extração extensiva da madeira e na empregabilidade uma oportunidade concreta para "melhorar de vida".

Os aspectos observados na Flona Tapajós me permitem fazer inferências mais amplas sobre os limites e os desafios dos novos arranjos conservacionistas. Nesse sentido, uma constatação que se aplicaria a outros contextos é o fato de que as áreas públicas destinadas à proteção ambiental ainda operam com perspectivas de controle dicotomizantes - cultura/natureza, área de uso/área de preservação - que são estranhas às práticas (saberes e formas de uso e de manejo) dos povos e comunidades tradicionais.

Logo, parece evidente que a gestão da conservação em lugares que foram inicialmente pensados e criados para que não houvesse moradores dentro precisa agora compatibilizar a proteção da natureza com as práticas que ali se desenvolveram historicamente. Entendo que o ponto de partida para isso está dado, embora seja sistematicamente ignorado. Isto é, se as áreas protegidas são criadas pelos atributos que exibem, e se estes são decorrentes das formas de interação que as pessoas e a natureza estabeleceram ao longo do tempo, as práticas aí desenvolvidas são potencialmente compatíveis com a conservação.

Sendo assim, algumas ideias precisam ser revistas (ou pelo menos relativizadas), como é o caso da noção de contrapartida, que sugere o estabelecimento de limites e restrições em troca dos benefícios que as populaçóes tiram dos recursos manejados. Do mesmo modo, as medidas compensatórias, que visam atenuar os efeitos das restrições sobre a produção material e imaterial da existência, deveriam ser amplamente discutidas - com e pela própria comunidade -, levando-se em conta não apenas suas prometidas vantagens, mas também seus possíveis efeitos negativos.

Deve-se, no mínimo, supor que há algo errado quando os modos próprios de existência de uma comunidade são alterados em nome daquilo que, reconhecidamente, é seu potencial e sua grande virtude: produzir sustentabilidade e justiça socioambiental. Nesse caso, é urgente avaliar se determinadas práticas de proteção ambiental não estão simplesmente contribuindo para o apagamento de regimes de uso, práticas de manejo e territorialidades, sem que isso represente ganhos à conservação. Por vezes, o que se condena ao aniquilamento são justamente relaçóes de reciprocidade comprovadamente sustentáveis.

Em síntese, embora os novos arranjos conservacionistas representem um avanço importante na 
defesa dos direitos de povos e comunidades tradicionais, eles não são refratários aos discursos e às práticas de gestão mercantil e ecoeficiente da natureza. Tal como numa guerra ontológica, a "razão instrumental do Estado" e o ideário da modernização ecológica podem produzir efeitos devastadores sobre os modos próprios de existir dessas populaçôes (Little, 2002, p. 259).

\section{Notas}

1 Ver: Projeto de Desenvolvimento Sustentável (Portaria Incra n. 447/1999); SNUC (Lei n. 9.985/2000); Política Nacional de Desenvolvimento Sustentável de PCTs (Decreto n. 6.040/2007); Conselho Nacional de PCTs (Decreto n. 8.750/2016).

2 Para garantir o anonimato dos sujeitos, as falas serão citadas ao longo do texto sem qualquer referência direta ou indireta a seus enunciadores. A pesquisa conta com a autorização de no 4983-1, emitida em 27 de junho de 2013, pelo Sistema de Autorização e Informação da Biodiversidade (SISBIO). As consultas de consentimento para registro audiovisual e uso das falas nos relatórios de pesquisa e eventuais publicaçóes, foram realizadas no momento dos diálogos e entrevistas.

3 Comunidades caboclas: São Domingos, Maguari, Jamaraquá, Acaratinga, Jaguarari, Pedreira, Piquiatuba, Marai, Tauari, Pini, Chibé, Prainha I, Prainha II, Itapaiuna e Paraíso. Comunidades indígenas: Takuara, Bragança, Marituba.

4 Em 1995 foi realizado um plebiscito em que a maioria das comunidades optou por ficar fora da Flona. Em 2003, nova consulta foi realizada alterando a decisão de 1995 .

5 Designarei como entrevistado 1, entrevistado 2 e entrevistado 3, profissionais que trabalham na gestão da $\mathrm{UC}$ e engenheiros terceirizados que atuam nas atividades de manejo florestal em larga escala.

6 O Decreto n. 8.750, de 9 de maio de 2016, transformou a Comissão Nacional de Povos e Comunidades Tradicionais em Conselho Nacional.

7 Segundo o MMA, o Bolsa Verde "funciona como um incentivo às comunidades para que continuem usando, de forma sustentável, os territórios onde vivem". Disponível em: <http://www.mma.gov.br/desenvolvimento-rural/bolsa-verde>. Acesso em: 31 jan. 2017.

8 Maria Tereza Jorge Pádua esteve à frente do Departamento de Parques do Instituto Brasileiro de De- senvolvimento Florestal (IBDF) na década de 1970. Entusiasta da proteção integral, é uma das vozes mais críticas aos novos arranjos conservacionistas.

9 Essas atividades estão previstas em Florestas Nacionais desde o Decreto n. 1298, de 27 de outubro de 1994.

10 Sobre ontologias e relaçóes entre humanos e não humanos nas comunidades caboclas do Tapajós, ver Wawzyniak (2010).

11 As questôes aqui levantadas, inspiradas pelas análises de Almeida (2013) sobre o manejo da caça no contexto do Alto Juruá, compóem uma nova agenda de pesquisa em desenvolvimento na Flona Tapajós.

\section{BIBLIOGRAFIA}

ADAMS, Cristina et al. (2006), Sociedades caboclas amazônicas: modernidade e invisibilidade. São Paulo, Annablume.

ALIER, Martinez. (2011), O ecologismo dos pobres. São Paulo, Contexto.

ALMEIDA, Alfredo Wagner. (2006), Terras de quilombos, terras indigenas, "babaçuais livres", "castanhais do povo": terras tradicionalmente ocupadas. Manaus, PPGSCA-UFAM.

ALMEIDA, Luciana. (2012), "Economia verde: a reiteração de ideias à espera de açōes”. Estudos Avançados, 26 (74). Disponível em: <http:// www.scielo.br/scielo.php?script=sci_arttext $\&$ pid $=$ S0103-40142012000100007>. Acesso em: 30 jun. 2016.

ALMEIDA, Mauro. (2009), "Populações tradicionais e conservação ambiental”, in M. C. Cunha, Cultura com aspas, São Paulo, Cosac Naify.

ALMEIDA, Mauro. (2013), "Caipora e outros conflitos ontológicos". Revista de Antropologia da UFSCAR, 5 (1): 7-28. Disponível em: <http://www.rau.ufscar.br/wp-content/ uploads/2015/05/vol5no1_01.MauroAlmeida. pdf>. Acesso em: 20 mar. 2017.

BACHA, Carlos José Caetano \& RODRIGUEZ, Luiz Carlos Estraviz. (2004), Impactos socioeconômicos do Projeto ITTO na Floresta Nacional do Tapajós. Piracicaba (SP), Instituto de Pesquisas e Estudos Florestais.

BARRETO FILHO, Henyo T. (2006). "Populaçôes tradicionais: introdução a uma críti- 
ca ecológica política de uma noção", in C. Adams et al., Sociedades caboclas amazônicas: modernidade e invisibilidade, São Paulo, Annablume.

BENSUSAN, Nurit \& PRATES, Ana Paula. (2014), A diversidade cabe na unidade? Áreas protegidas no Brasil. Brasília, IEB/Mil Folhas.

BICALHO, Ana Maria de Souza Mello \& HOEFLE, Scott William. (2014), "Política ambiental e conflito social na Floresta Nacional do Tapajós e no Parque Nacional da Amazônia”. Anais do I Congresso Brasileiro de Geografia Politica, Geopolítica e Gestão do Território.

BRASIL. (2002), Lei n. 9.985. Regulamenta e institui o Sistema Nacional de Unidades de Conservação (SNUC) da Natureza. Disponível em: <http://www.planalto.gov.br/ccivil_03/leis/ 19985.htm>. Acesso em: 16 jun. 2013.

CASTRO, Fábio Fonseca. (2013), "A identidade denegada: discutindo as representaçóes e autorrepresentaçóes dos caboclos da Amazônia”. Revista de Antropologia, 56 (2). Disponível em: $<\mathrm{http}$ //www.revistas.usp.br/ra/article/viewFile/82538/85513>. Acesso em: 30 jun. 2016.

CUNHA, Manuela Carneiro da. (2009), "Relações e dissensões entre saberes tradicionais e saber científico", in M. C. Cunha, Cultura com aspas, São Paulo, Cosac Naify.

DESCOLA, Philippe. (2001), "A natureza: um conceito em sursis?", in G. Pessis-Pasternak, A ciência: Deus ou diabo?, São Paulo, Editora Unesp.

DIEGUES, Antonio Carlos. (2004), Comunidades tradicionais e manejo dos recursos naturais na Mata Atlântica. São Paulo, Hucitec.

DIEGUES, Antonio Carlos. (2008), O mito da natureza intocada. São Paulo, Hucitec.

ESCOBAR, Arturo. (2010), Territorios de diferencia: lugar, movimientos, vida, redes. Colômbia, Envión.

FAVILLA, Kátia. (2017), Encontros neocoloniais: o Estado brasileiro e os povos e comunidades tradicionais. Dissertação de mestrado, Brasília, UnB.

GODELIER, Maurice. (1974), "Considerations théoriques et critiques sur le problème des rapports entre l'homme et son environement". Information sur les Sciences Sociales, 13 (6): 31-60.
HAESBAERT, Rogério. (2003), "Da desterritorialização à multiterritorialidade". Boletim Gaúcho de Geografia, 29: 11-24.

HAESBAERT, Rogério. (2004), O mito da desterritorialização: do fim dos territórios à multiterritorialidade. Rio de Janeiro, Bertrand Brasil.

IBAMA-MMA. (2004), Floresta Nacional do Tapajós: Plano de Manejo. Disponível em: <http:// observatorio.wwf.org.br/site_media/upload/ gestao/planoManejo/PM_flona_tapajos.pdf>. Acesso em: 16 jun. 2013.

IORIS, Edviges. (2000), "Conflitos em unidades de conservação com populaçóes locais: o caso da Floresta Nacional do Tapajós”. Anais da 22 Reunião Brasileira de Antropologia. Disponível em: <http://www.abant.org.br/conteudo/ANAIS/CD_Virtual_22_RBA/pdf/ F03\%20Edviges\%20Ioris.pdf >. Acesso em: 16 jun. 2013.

LACEY, Hugh. (2012), "Pluralismo metodológico, incomensurabilidade e o status científico do conhecimento tradicional". Scientiae Studia, 10 (3): 425-453. Disponível em: <http://www. scielo.br/scielo.php?script=sci_arttext $\&$ pi$\mathrm{d}=$ S1678-31662012000300002>. Acesso em: 16 jun. 2016.

LEROY, Jean-Pierre. (1991), Uma chama na Amazônia. Rio de Janeiro, Vozes.

LINS E SILVA, Tatiana. (1980), Os curupiras foram embora: economia, politica e ideologia em uma comunidade amazônica. Dissertação de mestrado, Rio de Janeiro, Museu Nacional.

LITTLE, Paul. (2002), Territórios sociais e povos tradicionais no Brasil: por uma antropologia da territorialidade. Brasília, Editora da UnB. (Antropologia, n. 322).

LITTLE, Paul. (2006), Mapeamento conceitual e bibliográfico das comunidades tradicionais no Brasil. Brasília, Ministério do Meio Ambiente.

MOSCOVICI, Serge. (2007), Natureza: para pensar a ecologia. Rio de Janeiro, Instituto Gaia.

NOGUEIRA, Mônica Celeida Rabelo. (2017), Gerais a dentro e a fora: identidade e territorialidade entre geraizeiros do norte de Minas Gerais. Brasília, IEB.

NUGENT, Stephen. (2006), “Utopias e distopias na paisagem social amazônica”, in C. Adams et al. 
Sociedades caboclas amazônicas: modernidade e invisibilidade, São Paulo, Annablume.

PÁDUA, Maria Tereza Jorge. (1979), Os parques nacionais no Brasil. São Paulo, José Olympio.

PÁDUA, Maria Tereza Jorge. (2011), “Do sistema nacional de unidades de conservação", in $\mathrm{R}$. Medeiros e F. F. S. Araújo, Dez anos do sistema nacional de unidades de conservação da natureza: liçóes do passado, realizaçóes presentes e perspectivas para o futuro, Brasília, MMA.

PORTO, Marcelo Firpo; PACHECO, Tania \& LEROY, Jean Pierre. (2013), Injustiça ambiental e saúde no Brasil: o mapa de conflitos. Rio de Janeiro, Fiocruz.

PORTUGUEZ, Anderson Pereira; SEABRA, Giovanni \& QUEIROZ, Odaléia Telles M. M. (2012), Turismo, espaço e estratégias de desenvolvimento local. João Pessoa, Editoras da UFPB.

REIS DA SILVA, Ana Tereza. (2015), "A conservação da biodiversidade entre os saberes da tradição e da ciência”. Estudos Avançados, 29 (83): 233-259. Disponível em: <http://www. scielo.br/scielo.php?script $=$ sci_arttext $\&$ pi$\mathrm{d}=$ S0103-40142015000100233 >. Acesso em: 13 maio 2015.

SANTOS, Boaventura de Sousa (org.). (2005), Semear outras soluçôes: os caminhos da biodiversidade e dos conhecimentos rivais. Rio de Janeiro, Civilização Brasileira.

SHIRAISHI NETO, Joaquim (org.). (2007), Direito dos povos e das comunidades tradicionais no Brasil. Manaus, UFAM.

WAWZYNIAK, Valentin. (2010), "Humanos e não humanos no universo transformacional dos ribeirinhos do rio Tapajós - Pará". Anais da 27a Reunião Brasileira de Antropologia. Disponível em: <http://www.uel.br/revistas/ $\mathrm{uel} / \mathrm{index} . \mathrm{php} / \mathrm{mediacoes} / \mathrm{article} / \mathrm{view} / 2012$. v17n1p17/10986>. Acesso em: 18 dez. 2016.

VAZ, Florêncio. (2004), "As comunidades Munduruku na Flona Tapajós”, in F. Ricardo (org.), Terras indígenas e unidades de conservação, São Paulo, ISA. 


\section{ÁREAS PROTEGIDAS, POPULAÇÓES TRADICIONAIS DA AMAZÔNIA E NOVOS ARRANJOS CONSERVACIONISTAS}

\section{Ana Tereza Reis da Silva}

Palavras-chave: Áreas Protegidas; Amazônia; Conservação; Povos Tradicionais; Território.

O reconhecimento de que é possível conciliar modos de vida de Povos e Comunidades Tradicionais (PCTs) com a conservação da biodiversidade desencadeou a criação de dispositivos legais em favor da permanência desses sujeitos em suas terras. Contudo, as áreas protegidas seguem sendo espaços em disputa, nos quais se projetam os interesses sociais pelo território, como meio de produção material e imaterial da vida, os interesses que visam destinar esses espaços exclusivamente à proteção ambiental e os interesses de mercado, que permeiam muitas das práticas incentivadas em Unidades de Conservação. Neste artigo, apresento os contornos que esses conflitos assumem na Floresta Nacional do Tapajós (Flona Tapajós), onde o "direito de ficar" impôs condicionalidades à população, isto é, restrições de uso e a introdução de novas práticas que têm modificado as relaçóes comunitárias e as dinâmicas socioeconômicas do lugar.

\section{PROTECTED AREAS, AMAZONIAN TRADITIONAL PEOPLE AND NEW CONSERVATIONIST ARRANGEMENTS}

\section{Ana Tereza Reis da Silva}

Keywords: Protected Areas; Amazon; Conservation; Traditional Peoples; Territory.

The acknowledgement that it is possible to reconcile lifestyles of Traditional Peoples and Communities (PCT) with the conservation of biodiversity has triggered the creation of legal mechanisms in favor of the permanence of these subjects in their lands. Nevertheless, protected areas continue to be disputed spaces, on which social interests are projected on the territory, as a means of material and immaterial production of life, interests in designating those spaces exclusively for environmental protection and interests in commerce, which permeates many of the encouraged practices in Conservation Units. In this article, I will present the character such conflicts assume in Tapajós National Forest (Flona Tapajós), where the "right to stay" imposed conditionstothe population, i.e., restrictions of use and the introduction of new practices that have changed the relations of the community as well as the socioeconomic dynamics of the place.

\section{AIRES PROTÉGÉES, POPULATIONS TRADITIONNELES D'AMAZONIE ET NOUVEAUX ARRANGEMENTS CONSERVATIONNISTES}

\section{Ana Tereza Reis da Silva}

Mots clés: Aires Protégées; Amazonie; Conservation; Peuples Autochtones; Territoire.

La reconnaissance de la possibilité de concilier les modes de vie des peuples et des communautés autochtones avec la préservation de la biodiversité a déclenché la création de dispositifs légaux qui permettent à ces individus de demeurer sur leurs terres. Cependant, les aires protégées continuent d'être des espaces disputés, dans lesquels sont projetés les intérêts sociaux pour le territoire, comme un moyen de production matérielle et immatérielle de la vie, les intérêts qui visent à destiner ces espaces exclusivement à la protection environnementale et les intérêts des marchés, qui imprègnent plusieurs des pratiques encouragées dans les Unités de Conservation. Dans cet article, je présente les caractéristiques de ces conflits au sein de la Forêt Nationale du Tapajós (Flona Tapajós), où le "droit de rester" impose des conditionnalités à la population, c'est-à-dire, des restrictions d'utilisation et d'introduction de nouvelles pratiques qui ont modifié les relations communautaires et les dynamiques socio-économiques de ce territoire. 